\title{
Watt per Square Meter
}

National Cancer Institute

\section{Source}

National Cancer Institute. Watt per Square Meter. NCI Thesaurus. Code C70438.

A SI derived unit of density of heat flow rate, irradiance, and radiant energy fluence rate equal to one watt per the unit area of one square meter. 